\title{
Cellular Responses to Tumor Necrosis Factor
}

\author{
Zheng-gang Liu' ${ }^{1}$ and Jiahuai Han ${ }^{2 *}$ \\ ${ }^{1}$ Cell and Cancer Biology Branch, Center of Cancer \\ Research, National Cancer Institute, National Institute of \\ Health, Bethesda, MD 20892, USA \\ 2Department of Immunology, The Scripps Research \\ Institute, 10550 North Torrey Pones Road, La Jolla, CA \\ 92037, USA
}

\begin{abstract}
TNF is a proinflammatory cytokine that plays an important role in many physiological and pathological conditions through the regulation of immunological reactions. Many of TNF functions have been proven to be cell type-specific, and the specificity of TNFinduced cellular responses in a given cell is determined by the specific intracellular signaling pathways that are activated by TNF. Although current information is insufficient to sort out how the cell type specificity is controlled by the different intracellular signaling pathways, a number of signaling pathways that are commonly activated in many types of cells by TNF have been revealed. This review weighs the current knowledge of these TNF-induced signaling pathways.
\end{abstract}

\section{Introduction}

Tumor necrosis factor $\alpha$ (TNF) is a proinflammatory cytokine produced mainly by activated macrophages or monocytes and plays an important role in diverse cellular events, such as the production of other cytokines, cell proliferation, differentiation and apoptosis (Beutler et al., 1988; Tartaglia et al., 1992; Rothe et al., 1992; Tracey et al., 1993; Beyaert et al., 1994). TNF was originally identified as a factor that leads to rapid hemorrhagic necrosis of transplantable tumors in mice (Carswell et al., 1975). It was identical to a factor named cachectin that was purified at almost the same time on the basis of its ability to suppress the expression of lipoprotein lipase in fat (Beutler et al., 1984). Approximately one third of transformed cell lines were shown to be susceptible to the cytolytic action of TNF (Sugarman et al., 1985). However, because of its toxicity in animals and humans, TNF did not fulfill the initial expectations that it would be useful in the treatment of cancer. It is clear that TNF also affects normal cells. TNF activates a variety of cells, such as neutrophils, endothelial cells, and fibroblasts. The cellular changes in response to TNF are cell-type dependent. For example, TNF may modify the anticoagulant properties of endothelial cells, promote $\mathrm{T}$ cell proliferation, cause bone resorption, and induce the release of other inflammatory cytokines in many

*For correspondence. Email jhan@scripps.edu; Tel. 1-858-7848704; Fax. 1-858-7848665. different cells. Inappropriate production of TNF has been implicated in the pathogenesis of both acute and chronic inflammatory diseases such as septic shock, AIDS, arthritis and cancer (Beutler et al., 1988; Tracey et al., 1993). The studies in the last two decades have provided a large amount of information regarding the biological function of this important cytokine and have been reviewed by a number of excellent reviews (Beutler et al., 1988; Tartaglia et al., 1992; Rothe et al., 1992; Tracey et al., 1993; Beyaert et al., 1994). The intracellular signaling pathways of TNF have been studied intensively in the past several years and a number of important components in these pathways have been identified. The commonality of TNF-induced cellular responses in different cells is that they are all initiated by the binding of TNF to receptors present on virtually all cells throughout the body (Tartaglia et al., 1992; Rothe et al., 1992). Though the downstream events may vary to some extent in different types of cells, current information does not allow us to compare the specific pathways in different types of cells. In this review we have highlighted the intracellular signal transduction pathways that are known to be activated in TNF-stimulated cells.

\section{The Molecular Mechanism of TNF Signaling}

TNF-induced cellular responses are mediated by either one of the two TNF receptors, TNF-R1 (p55) and TNF-R2 (p75), both of which belong to the TNF receptor super-family (Smith et al., 1994; Nagata et al., 1995). Almost all cell types express at least one of the two kinds of TNF receptors (Smith et al., 1994; Nagata et al., 1995). The two receptors display no significant homology in their intracellular domains, suggesting that the two receptors may elicit different intracellular signals. Genetically engineered mice lacking TNF-R1 are moderately resistant to the lethal effect of lipopolysaccharides but highly susceptible to the infection by Listeria monocytogenes (Pfeffer et al., 1993). TNF-R2 knockout mice are moderately resistant to the lethal effect of TNF itself (Erickson et al., 1994). A double knockout of TNF-R1 and TNF-R2 results in a sum of these phenotypic effects. Thus, the two TNF receptors have different functions in vivo. The first step of TNF signaling is believed to be ligand-induced oligmerization of the receptor molecules. Initiation of signaling occurs by recruitment of cytosolic effector proteins that associated with the cytoplasmic domains of the TNF receptors. To date, most studies related with TNF-induced cellular responses were on TNF-R1-mediated pathways. For TNF-R1 signaling, the first molecule recruited to TNF-R1 is known as TRADD, a death domain protein (Hsu et al., 1995). In response to TNF, TRADD is recruited to TNF-R1 through the interaction between the death domains of these two proteins (Hsu et al., 1995). TRADD subsequently recruits other effectors, such as TRAF2, RIP, FADD, CIAP1, CIAP2 and A20, to the TNF-R1 complex (Hsu et al., 1996a; Hsu et al., 1996b; Shu et al., 1996; Lin et al., 1999; Devin et al., 2000; Zhang 


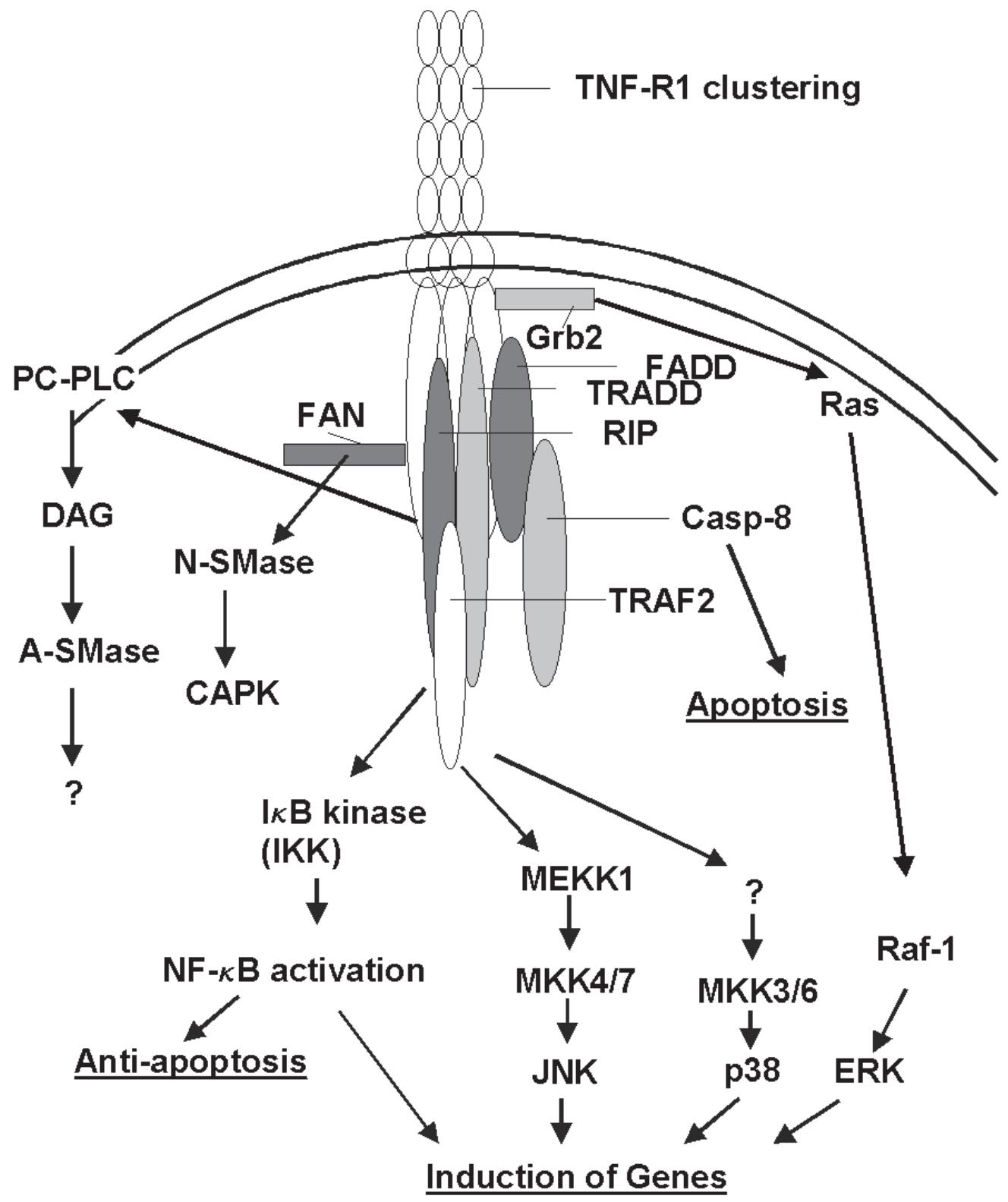

Figure 1. The intracellular signaling pathways downstream of TNF-R1. See text for details.

et al., 2000). These effector proteins then mediate the activation of proteases, phospholipases, protein kinases, and transcription factors respectively as shown in Figure 1. The signaling pathway of each TNF-induced cellular response is discussed separately below in detail.

\section{NF-kB Pathway}

$\mathrm{NF}-\mathrm{\kappa B}$ is one of the key transcription factors that mediate many TNF-induced cellular responses. In most types of cells, the activity of NF-KB can be potently elevated by TNF treatment (Israel et al., 1989; Israel et al., 1989). Inactive NF- $\mathrm{KB}$ is sequestered in the cytoplasm through its interaction with the inhibitory proteins, known as IкBs
(Baeuerle et al., 1996). In response to various stimuli including TNF, IкBs are phosphorylated by $І \kappa B$ kinases (IKKs) (Karin et al., 2000). Then the Phosphorylated IкBs are polyubiquitinated and subsequently degraded by the proteasome (Karin et al., 2000). The degradation of IאBs results in the release of NF- $\mathrm{kB}$ and allows its translocation into the nucleus and the subsequent activation of its target genes (Baeuerle et al., 1996). Therefore, IKK activation is a key step in the activation of $\mathrm{NF}-\kappa \mathrm{B}$. The molecular mechanism of TNF-induced IKK and NF-кB activation has been intensively studied in the last several years. The first identified effector molecule of the TNF-R1 signaling complex was TRAF2, although it was cloned as a binding protein of TNF-R2 (Rothe et al., 1994; Rothe et al., 1995). 
After TRADD was isolated as the key adapter protein of the TNF-R1 signaling complex, TRAF2 was found to be recruited to the TNF-R1 signaling complex through its interaction with TRADD and to play an important role in TNF-R1-mediated NF-KB activation (Hsu et al., 1996b). While the TRAF domain of TRAF2 is essential for its interaction with the $\mathrm{N}$-terminal region of TRADD, the ringand zinc-finger regions of TRAF2 are responsible for transducing the TNF signal to TRAF2's downstream targets (Baud et al., 1999). Similarly, another critical component of the TNF-R1-signaling complex, RIP, a death domain kinase which was initially identified as a Fas binding protein (Hsu et al., 1996a), was also found to be recruited to the TNF-R1 signaling complex by TRADD and to be a key effector of TNF-induced NF-кB activation (Hsu et al., 1996a). It is believed that RIP is recruited to TRADD through the interaction between their death domains (Hsu et al., 1996a). However, the kinase activity of RIP is not required for RIP to transduce TNF signaling (Hsu et al., 1996a; Devin et al., 2000). The important roles of TRAF2 and RIP in TNF-induced NF-KB activation have been confirmed by genetic deletion of these molecules in mice (Yeh et al., 1997; Kelliher et al., 1998).

Several other proteins, including A20, CIAP1 and CIAP2, were also found to be recruited to the TNF-R1 complex in response to TNF treatment (Shu et al., 1996; Zhang et al., 2000). A20 is a zinc finger protein induced by TNF and down-regulates NF-KB activation (Opipari et al., 1990). Although A20 was found in the TNF-R1 complex, A20 does not inhibit TNF-induced nuclear translocation and DNA binding of $N F-\kappa B$, suggesting that $A 20$ functions downstream of the initiation of NF- $\mathrm{kB}$ activation (Heyninck et al., 1999). Since A20 was found to interact with a protein known as $A B I N$, whose expression also inhibits NF-KB activation, it was proposed that $A 20$ acts via its interaction with ABIN to suppress NF- $\mathrm{KB}$-mediated transcription (Heyninck et al., 1999). Genetic deletion of A20 resulted in the prolonged activation of IKK in response to TNF (Lee et al., 2000). The function of clAP1 and clAP2 in NF-kB activation is still unclear. Interestingly, both clAP1 and cIAP2 are ring-finger-containing proteins and have been shown to function as E3 ligases (Yang et al., 2000). Therefore, it is possible that, much like the role of c-CBL in EGF signaling (Levkowitz et al., 1999), clAP1 and clAP2 are involved in turning off TNF signaling.

Downstream of the effector proteins mentioned above, the mechanism that leads to the activation of IKK is less clear. It has been suggested that the MAP3Ks, such as NIK and MEKK1, mediate TNF-induced IKK activation (Chen et al., 1996; Lee et al., 1997; Malinin et al., 1997; Regnier et al., 1997). However, deletion of either of these two molecules genetically in mice did not affect TNFinduced IKK and NF-кB activation (Xia et al., 2000; Yujiri et al., 2000; Yin et al., 2001). Therefore, it is unlikely that NIK and MEKK1 play any critical role in TNF-induced NF$\kappa B$ activation, although the possibility that these kinases may have redundant functions in this process has not been completely ruled out. Most recently, another MAP3K, MEKK3, has been found to be involved in TNF-induced IKK and NF-KB activation (Yang et al., 2001). In MEKK3 null MEF cells, the TNF-induced IKK and NF-KB activation has been severely impaired. Although it seems that MEKK3 functions downstream of TRAF2 and RIP and upstream of $\mathrm{IKK}$, it is still not clear whether MEKK3 is the IKK kinase in response to TNF.

IKK is a kinase complex and is composed of three subunits: IKK $\alpha /$ IKK1, IKK $\beta /$ IKK2 and IKK $\gamma /$ NEMO (DiDonato et al., 1997; Mercurio et al., 1997; Regnier et al., 1997; Woronicz et al., 1997; Zandi et al., 1997; Yamaoka et al., 1998; Rothwarf et al., 1998). Both IKK $\alpha / I K K 1$ and $\mathrm{IKK} \beta / \mathrm{IKK} 2$ are catalytic subunits while IKK $\gamma / \mathrm{NEMO}$ is a regulatory subunit. Recently, studies reported that IKK was recruited to the TNF-R1 complex and was activated in response to TNF treatment (Devin et al., 2000; Zhang et al., 2000). The interaction between RIP and IKK $\gamma /$ NEMO has been detected in the yeast two hybrid system as well as in overexpression experiments (Zhang et al., 2000). But with TRAF2 null MEF cells, it has been found that TRAF2 is essential for the recruitment of IKK to the TNF-R1 signaling complex (Devin et al., 2000). Most recently, it has been shown that TRAF2 recruits IKK to the TNF-R1 complex through its interaction with IKK $\alpha / \mathrm{IKK} 1$ and IKK $\beta$ / IKK2 (Devin et al., 2001). Using NEMO/IKK $\gamma$ deficient Rat$15 \mathrm{R}$ cells, it has also been shown that the interaction between RIP and IKK $\gamma /$ NEMO plays a limited role in this recruitment process. Although both RIP and IKK $\gamma / \mathrm{NEMO}$ are required for IKK activation, the exact mechanism of this activation process is still unknown. It is possible that the RIP-IKK $\gamma / \mathrm{NEMO}$ interaction results in conformation changes in IKK and, in turn, leads to the autophosphorylation and subsequent activation of IKK. Another possibility is that RIP is required for recruiting the IKK kinase, most likely a MAP3K such as MEKK3, and then the interaction between RIP and IKK $\gamma /$ NEMO primes the IKK kinase to activate IKK.

Several other kinases such as GSK3 $\beta$ and PKC were also suggested to be involved in TNF-induced NF-KB activation but they were not required for IKK activation (Hoeflich et al., 2000; Sanz et al., 1999). The role of these kinases in TNF-induced NF- $\mathrm{kB}$ activation seems to be limited to regulating NF- $\mathrm{B}$ transcription activity. However, further examination into whether these kinases directly modulate NF- $\mathrm{KB}$ activity in response to TNF needs to be done.

\section{ERK Pathway}

ERK (extracellular signal-regulated kinases) pathway is one of the MAP kinase pathways that are activated by TNF. Since sphingomyelinase (SMase) and ceramide activate ERK, it was suggested that TNF induces ERK activation via lipid second messenger (Stout et al., 1993). This idea was further supported by the studies aimed at dissecting the signaling pathway between acidic and neutral SMases (Wiegmann et al., 1994). It was found that TNF-R1 deletion mutants displayed a loss-of-function phenotype with regard to activation of PC-specific phospholipase C (acidic SMase pathway), yet retained their capacity to signal stimulation of ERK, indicating that ERK activation is downstream of neutral SMase (Wiegmann et al., 1994). The later work identified an adaptor protein FAN (factor associated with neutral SMase activation) that linked TNF-R1 to neutral 
SMase (Adam-Klages et al., 1996). There is evidence that ceramide generated by neutral SMase leads to the activation of ceramide-activated protein (CAP) kinase (also known as kinase of suppressor of Ras) and that c-Raf-1 is downstream of CAPK (Yao et al., 1995; Zhang et al., 1997).

Grb2 is an adapter protein and was found to bind to the tyrosine kinase receptor family members (Buday, 1999). Although TNF-R1 does not possess tyrosine kinase activity, Grb2 was found to interact with TNF-R1 using a two-hybrid screening (Hildt et al., 1999). Using deletion mutants Hildt and Oess revealed that the $\mathrm{C}$-terminal $\mathrm{SH} 3$ domain of Grb2 binds to a PLAP motif at amino acids 237 to 240 in TNFR1 (Hildt et al., 1999). The binding of Grb2 to the PLAP motif is essential for the activation of c-Raf- 1 by TNF; disruption of the TNF-R1/Grb2 complex by cell permeable peptides inhibited TNF-induced c-Raf- 1 activation and deletion of PLAP in TNF-R1 rendered TNF-R1 incapable of activating c-Raf-1 (Hildt et al., 1999). Although the Grb2 and TNF-R1 interaction is required for C-Raf-1 and subsequently ERK activation, the signaling through Grb2 may not be sufficient for c-Raf-1 activation. In the same study, Hildt and Oess reported that interfering with neutral SMase pathway by disruption of the TNF-R1/FAN interaction also blocked c-Raf-1 activation (Hildt et al., 1999). A model in which ERK activation requires two paralleled signals was proposed. However, conflicting results have been reported. A recent study using fan-/- cells revealed that TNF-induced ERK1/2 activation was not affected by the FAN knockout (Segui et al., 2001).

\section{JNK Pathway}

JNK (c-Jun N-terminal kinase), also known as SAPK (stress-activated protein kinase), is another MAPK that is rapidly and potently activated by TNF in many types of cells (Derijard et al., 1994). JNK is distantly related to the ERK, to which JNK exhibits about $40 \%$ identity. Three genes that encode JNK have been identified as jnk1, jnk2 and jnk3 by molecular cloning (Derijard et al., 1994; Sluss et al., 1994; Mohit et al., 1995; Kallunki et al., 1996). The alternative splicing of the transcripts of these three genes generates at least $10 \mathrm{JNK}$ isoforms with molecular masses of 46 and $55 \mathrm{kDa}$ (Gupta et al., 1996). All of these isoforms of JNK can be activated by TNF. It is believed that JNK is activated through a MAP kinase cascade in response to TNF (Davis, 1999). Although MKK7/JNKK2 has been identified recently as a specific JNK kinase following TNF treatment (Tournier et al., 2001), the corresponding MAP3K is still unknown. Several MAPKKKs, including MEKK1 and ASK1, have been suggested to mediate TNF-induced JNK activation (Liu et al., 1996; Ichijo et al., 1997). However, recent studies with genetic deletions of these genes have excluded their involvement in JNK activation in response to TNF (Yujiri et al., 2000; Tobiume et al., 2001).

It is not clear how the TNF signal is transduced from the TNF-R1 signaling complex to MAP3K. The roles of some effector molecules of TNF signaling including TRAF2, RIP and A20 have been examined and it has been shown that the dominant negative mutant of TRAF2 could completely block TNF-induced JNK activation (Liu et al., 1996; Natoli et al., 1997). When TRAF2 was genetically deleted, TNF-induced JNK activation dramatically diminished (Nguyen et al., 1999). These studies indicated that TRAF2 plays an essential role in TNF-induced JNK activation. In contrast, the role of RIP in this process is less clear. Early studies with the dominant negative mutant of RIP suggested RIP was required for TNF-induced JNK activation (Liu et al., 1996). But the study with genetic deletion of RIP detected only a minor decrease in JNK activation in RIP-/- cells in response to TNF (Kelliher et al., 1998). Therefore, the role of RIP in this process needs further study. Although it plays a role in TNF-induced NF$\kappa B$ activation, it seems that A20 is not involved in TNFinduced JNK activation (Zazgornik et al., 1975).

\section{p38 Pathway}

p38 is a MAP kinase which has been identified as an important signaling molecule in inflammation (Han et al., 1994). TNF is a strong activator of p38 in a variety of different cell types (Raingeaud et al., 1995). To date, four different members of the p38 group MAP kinases have been identified in mammals: p38 $\alpha$ (or p38, RK, CSBP), p38 $\beta$ (or p38-2), p38 $\gamma$ (or ERK6, SAPK3), and p38 (or SAPK4) (Ono et al., 2000). It appears that all of the four p38 isoforms are activated by TNF stimulation; however, the majority of the current data is derived from the research on the p38 $\alpha$ activation in TNF-treated cells. It is known that the upstream MAP kinase kinases of p38 $\alpha$ are MKK3 (or MEK3) and MKK6 (or MEK6) (Derijard et al., 1995; Han et al., 1996). The further upstream MAP3K in this pathway is not clearly understood. Since ASK1 and TAK1 were reported to be activated in TNF-stimulated cells, these two kinases may play a role in mediating $p 38 \alpha$ activation in the TNF signaling pathway. However, the most recent study with the genetic deletion of Ask1 indicated that Ask1 did not play an essential role in TNF-induce p38 activation (Tobiume et al., 2001). Very little is known about the effectors downstream of TNF-R1 that lead to p38 activation. Although over-expression of TRAF2 can lead to p38 activation in various types of cells, the requirement of TRAF2 in mediating p38 activation has not been confirmed in TRAF2-/- cells. There is no information available as to whether other effectors, such as RIP, have any role in TNFinduced p38 activation. The signaling events between these effectors and the p38 MAP kinase cascade are completely unknown at the present time.

\section{Acidic Sphingomyelinase (A-SMase) Pathway}

Activation of the phospholipid transmission pathway by TNF was first reported nine years ago (Schutze et al., 1992). In a study to explore the mechanisms of TNF-induced NF$\kappa \mathrm{B}$ activation, Schutze et al had found that PC-specific phospholipase C (PC-PLC) and A-SMase were activated in TNF treated U937 cells. Their data suggested that generation of 1,2-diacylglycerol produced by a TNF responsive $\mathrm{PC}$-specific phospholipase $\mathrm{C}$ subsequently activated A-SMase. Ceramide, generated by sphingomyelin breakdown catalyzed by A-SMase, is the second messenger in triggering downstream NF-KB activation. Subsequent work from the same group of investigators 
mapped the sequence in TNF-R1 which is required for ASMase activation. As little as a 32 amino acid truncation of TNF-R1 at the C-terminus causes a defect in TNF-induced A-SMase activation (Wiegmann et al., 1994). A later study showed that FADD is required for TNF-induced A-SMase activation (Wiegmann et al., 1999). Although A-SMase is activated by TNF, its involvement in NF-кB activation became uncertain after further studies were performed. Inhibition of A-SMase by a specific inhibitor SR33557 had no effect on TNF-mediated NF- $\kappa B$ activation in ML-1a cells (Higuchi et al., 1996). TNF-induced degradation of IKB- $\alpha$ and nuclear translocation of NF-KB in embryonic fibroblasts derived from an a-smase-/- strain is the same as in cells from the wild-type mice (Zumbansen et al., 1997). Thus, it is unclear whether A-SMase has no role whatsoever in TNF-induced NF- $\mathrm{NB}$ activation or if its role in NF- $\mathrm{BB}$ activation is cell type dependent.

\section{Neutral Sphingomyelinase (N-SMase) Pathway}

TNF activates not only an endosomal A-SMase but also a membrane-associated N-SMase (Wiegmann et al., 1994). The activation of A-SMase and N-SMase occurs through different mechanisms since the domain sequences in TNF$\mathrm{R} 1$ required for their activation are different (Wiegmann et al., 1994). As mentioned above, the A-SMase activation requires the $\mathrm{C}$-terminus of the TNF-R1. However, the sequence that is required for N-SMase activation was mapped to amino acids 309-319, which is in the middle of the cytoplasmic domain of TNF-R1 (Adam et al., 1996). Identification of FAN (factor associated with neutral SMase activation), which couples TNF-R1 to N-Smase, but not ASMase, further supported the notion that N-SMase and ASMase are two independent pathways (Adam-Klages et al., 1996; Kreder et al., 1999). In the same study, the ceramide generated by N-SMase, but not A-SMase, was suggested to activate the proline-directed serine/threonine protein kinase and phospholipase A2 (Wiegmann et al., 1994). It was reported later that the ceramide activated protein kinase is downstream of ceramide and can activate the Raf-ERK pathway (Yao et al., 1995). More recently, NSMase was shown to be involved in TNF-induced cell death (Segui et al., 2001). Dominant negative FAN abrogates TNF-induced ceramide generation and reduces caspase processing. In addition, fan-/- fibroblasts are resistant to TNF-induced cell killing (Segui et al., 2001). Conflicting with the previous reports, activation of ERK was not altered in fan-/- cells (Segui et al., 2001), indicating that the NSMase pathway is not related with ERK activation.

\section{TNF Signaling Related with Cell Death}

Although TNF was named for its ability to cause tumor regression, it only selectively kills certain type of cells (Sugarman et al., 1985; Beutler et al., 1988; Rothe et al., 1992; Tracey et al., 1993; Beyaert et al., 1994). It is now known that one of the reasons for this inefficiency is the activation of NF-kB in response to TNF treatment (Van Antwerp et al., 1998). Studies from several labs have demonstrated that NF- $\mathrm{KB}$ activation protects cells against TNF-induced apoptosis (Liu et al., 1996; Beg et al., 1996;
Van Antwerp et al., 1996; Wang et al., 1996). Inhibition of $N F-\kappa B$ activation rendered many types of cells TNF sensitive. Several of NF-кB's target genes, including clAP1, CIAP-2 and IEX-1L, have been suggested to have such anti-apoptotic effect (Wang et al., 1996; Wu et al., 1998). Recently, the existence of a TRAF2-dependent but NF$\kappa B$-independent anti-apoptotic pathway has been revealed through a genetic study (Yeh et al., 1997).

Substantial evidence supports the view that engagement of TNF-R1 triggers apoptosis in many different cells. The pro-apoptotic effect of TNF-R2 was only found in some circumstances. Dependent on the type of target cell, TNF-induced cell death could be necrotic or apoptotic. Apoptotic cell death is morphologically characterized by membrane blebbing, condensation of both the cell and chromatin, DNA fragmentation, and finally fragmentation of the cell into discrete membrane bound particles (Cohen et al., 1992; Kerr et al., 1972). Such changes are seen in a number of different cells, such as U937, PC60 and KYM cells, after TNF treatment (Tewari et al., 1995; Wright et al., 1992). The morphological changes of necrotic cell death include cell swelling, destruction of organelles and cell lysis (Golstein et al., 1991). TNF-treated murine L929 cells die with necrotic phenotype (Beyaert et al., 1994; Fiers et al., 1999). Both apoptosis and necrosis are initiated by TNF receptor I (TNF-RI) clustering and TRADD recruitment (Boldin et al., 1996; Fiers et al., 1999; Strasser et al., 2000). As shown in Figure 1, FADD is required for caspase-8 autoactivation, which plays a key role in TNF-induced apoptosis (Li et al., 1999). Active caspase-8 is an initiator caspase that either acts via cytochrome c (Cyt c) release or by the direct activation of effector caspases to execute apoptosis (Goossens et al., 1995). At least in some cells, such as MCF-7, the cyt c release is associated with TNFinduced apoptosis (Srinivasan et al., 1998). As with apoptosis, the TNF-induced necrotic pathway in L929 cells is also initiated by trimerization of the DD of TNF-RI (Vandevoorde et al., 1997; Fiers et al., 1999). Recruitment of TRADD also occurs in these cells. The two pathways may diverge downstream of TRADD since neither the known pro-apoptotic caspases including caspase-8, nor cyt $c$ release are involved in this death pathway (Vercammen et al., 1998; Fiers et al., 1999; Goossens et al., 1999). Moreover, the caspase inhibitor zVAD does not block TNF-induced L929 cell death, but in fact dramatically enhances TNF-induced cell killing (Vercammen et al., 1998). It was recently suggested that RIP may be responsible for TNF-induced necrosis (Holler et al., 2000). Despite the significant differences in the morphology of cell death, the apoptotic and necrotic pathways still share some common components downstream. Bcl-xL can prevent both apoptosis and necrosis (Kane et al., 1993; Shimizu et al., 1995). Metaxin, an outer mitochondrial membrane protein, was found to be required for both TNFinduced apoptosis and necrosis (Wang et al., 2001). Thus, the TNF activated cell death pathway may not be a linear cascade. Apoptosis or necrosis may be determined by the balance among the different branches of the singaling pathway.

A number of studies suggested that acidic compartments, mainly constituted by lysosomes, have a 
role in TNF-induced cell death (Liddil et al., 1989; Deiss et al., 1996; Monney et al., 1998; Guicciardi et al., 2000; Foghsgaard et al., 2001). It was reported twenty years ago that the activity of tumor necrosis serum-induced cell death can be inhibited by lysosomtropic agents such as chloroquine (Kull et al., 1981). In an analysis of a TNFresistant L929 line, Liddil et al reported more than ten years ago that a TNF resistant L929 cell sub-line had a 50\% reduction in total lysosomal protein levels in comparison with parental line (Liddil et al., 1989). The lysosomal protease cathepsin $\mathrm{D}$ was identified to be required for TNFinduced cell death by random gene disruption (Deiss et al., 1996). Cathepsin B, another lysosomal preotease, was recently reported to be involved in TNF-induced cell death by using cathepsin B -/- cells. (Guicciardi et al., 2000). It was proposed that cathepsin B acts upstream of cyt $C$ release from mitochondria. Another report suggested that lysosomal proteases may cleave bid, which in turn triggers cyt c release (Stoka et al., 2001). In addition to the possible role of lysosomes in initiating the cell death process, we have found that the lysosomes were dramatically enlarged during TNF treatment (our unpublished results). The enlargement of lysosomes may represent a self-digestion during the cell death process, so lysosomes may also participate in the execution of cell death. As we have discussed above, acidic SMase, located in acidic endosomes and/or lysosomes, was reported to be activated by TNF (Nanda et al., 1992). Resistance to radiationinduced apoptosis was reported in asmase-/- cells (Lozano et al., 2001); however, whether TNF-induced cell death was affected in asmase-/- cells was not addressed in this study. In contrast, a recent report suggested that ceramide formed within or accumulated in lysosomes is not the second messenger of apoptosis induced by various stress stimuli, one of which is TNF. The cells derived from patients with Farber disease, which has a genetic defect of ASMase, were equally sensitive to TNF-induced cell death as the wildtype cells (Segui et al., 2000). So it appears that lysosomal SMase may not be involved in the initiation of apoptosis.

\section{TNF Signaling Linked to Gene Induction}

The pleiotropic effect of TNF is not only due to its cytotoxity in certain types of cells, but is also a consequence of the gene induction caused by this cytokine. The number of genes that can be up-regulated by TNF stimulation is unknown, but it is known that almost all pro-inflammatory cytokines are induced by TNF stimulation. Other molecules, such as matrix proteases, that are involved in inflammatory diseases are either directly or indirectly induced by TNF in vivo. The intracellular signaling pathways activated by TNF are essential for the gene induction.

We have mentioned above that a number of TNFactivated intracellular signaling pathways have been revealed. NF-кB is known to be the primary transcription factor involved in the gene induction of inflammatory molecules since the $\kappa \mathrm{B}$ binding site(s) was found in the promoters of almost all TNF-inducible genes (Baeuerle et al., 1996). TNF-activated JNK may be important in the activation of genes containing the AP-1 site(s), a cis- element found in many inducible genes (Shaw et al., 1986: Whitmarsh et al., 1996). ERK, JNK and p38 pathways also target other transcription factors such as CREB, ATF1, ATF2, ELK-1, Sap1, MEF2, etc. (Robinson et al., 1997; Janknecht et al., 1997; Ono et al., 2000), that are directly or indirectly involved in TNF-induced gene activation. The relative role of the phospholipid transmission pathway activated by TNF in gene induction has proven difficult to establish unambiguously because conflicting results were reported regarding the activation of NF- $\mathrm{KB}$ by the A-SMase pathway and the activation of ERK by the N-SMase pathway (Schutze et al., 1992; Wiegmann et al., 1994; Yao et al., 1995; Zumbansen et al., 1997; Segui et al., 2001). Nevertheless, the potential involvement of these phospholipid transmission pathways in TNF-induced gene induction cannot be excluded.

It is well known that many of the genes induced in inflammatory responses are subject to regulation at the levels of mRNA stability and protein translation (Guhaniyogi et al., 2001). The AU-rich elements (ARE) in the 3'untranslated region of mRNA play a key role in mediating its stability and translation (Han et al., 1990; Kotlyarov A. et al., 1999; Kontoyiannis et al., 1999). It is worth noting that ARE can be found in the mRNA of almost all genes induced in inflammation. A number of ARE binding proteins have been identified, including AUF1, HuR and TTP (Peng et al., 1998; Fan et al., 1998; Carballo et al., 1998; Piecyk et al., 2000); however, information regarding whether and how these proteins regulate the ARE-bearing mRNA's stability or translation is very limited (Shyu et al., 2000). It was proposed that this regulation was related to mRNA transport from the nucleus to the cytosol and perhaps also to the location of mRNA (Shyu et al., 2000). A number of reports demonstrated the important role of p38 pathway in regulating $\mathrm{mRNA}$ stability and protein translation (Lasa et al., 2000; Holtmann et al., 2001; Kontoyiannis et al., 2001; Faour et al., 2001; Lasa et al., 2001). A gene knockout of MAPKAPK2, a downstream kinase of p38, conformed that the p38 pathway has a regulatory role in ARE-mediated mRNA stability and translational regulation (Kotlyarov A. et al., 1999). The involvement of JNK and ERK in regulation of mRNA stability and/or protein translation was also reported (Swantek et al., 1997; Chen et al., 1998; Sheng et al., 2001). Whether such a role can be applied to TNFinduced genes requires further investigation. The biggest gap in our knowledge now is how the signaling pathway(s) links with the proteins that directly interact with ARE in the mRNAs.

\section{TNF as a Target in the Treatment of Inflammatory Diseases}

The investigation of TNF was driven largely by practical goals. The isolation of TNF was a result of searching for endogenous factors that would act to destroy tumor cells. Unfortunately, the application of TNF in tumor treatment was proven to be unsuccessful. Because of a close relationship between TNF and inflammation, extensive clinical trials have been performed to test the effects of TNF blockage in a number of inflammatory diseases.

Monoclonal antibodies that selectively neutralize TNF 
were tested in treating septic shock. A randomized, controlled, double-blind, multicenter clinical trial showed no substantial benefit to the patients (Wherry et al., 1993; Abraham et al., 1995). One of the possible interpretations is that septic shock is a fulminate disease in which considerable damage may already have occurred before the initiation of therapy. Thus, blockage of TNF may not be an effective method to treat acute inflammatory diseases. In contrast, treatment of chronic inflammatory diseases, like rheumatoid arthritis (RA) and Crohn's disease, has been very successful (van Dullemen et al., 1995; Bathon et al., 2000). In the last two years, the US FDA and EU's Commission have approved etanercept and infliximab for use in the treatment of refractory RA. Etanercept is a fusion protein composed of $\mathrm{Fc}$ portion of IgG1 and the extracellular domain of TNF receptor II. Infliximab is a chimeric monoclonal antibody composed of murine variable and human constant regions. Both of them effectively bind to TNF and thereby inhibit its biological function. Intravenous injection of these TNF inhibitors rapidly decreased symptoms and slowed joint damage in patients more effectively than drugs such as methotrexate that are already in the market (Mikuls et al., 2001). Clinical trials using combinations of these biological reagents with methotrexate have also proven to be beneficial (Kremer, 2001). As TNF certainly has beneficial roles in vivo, we would expect side effects of long term TNF blockage. Indeed, systemic inhibition of TNF activity can cause a lupus-like syndrome. About one percent of patients undergoing TNF blockage through the treatment with etanercept or infliximab develop reversible systemic lupus erythematosus, and nearly $10 \%$ develop anti-DNA antibodies (Charles et al., 2000; Schaible, 2000). Since this syndrome is reversible, it did not prevent the application of etanercept and infliximab in RA patients.

\section{Perspectives}

TNF is one of the most intensively studied cytokines in the past twenty years, and this intensity will most likely not diminish in the coming years. Here we list a few possible directions of future TNF research. One emphasis of TNF research will be to translate our knowledge of this cytokine to clinical applications. As we have described above, directly targeting TNF has proven to be effective in treating some chronic inflammatory diseases. Targeting intracellular signaling molecules will be an alternative way to interfere with TNF functions. In addition, since many TNF-elicited cellular responses are cell-type dependent, interfering with the functions of different intracellular signaling molecules could provide opportunities to limit side effects of the treatment. Meanwhile, the study of the intracellular signaling pathways of TNF will continue to have great significance, since many gaps still exist in the signaling networks of this cytokine and, especially as we indicated above, the mechanism that controls the specificity of TNF signaling in different cell types has not been properly addressed at present time. Moreover, a number of TNF family members with distinguishing properties were identified in recent years and the studies of them have accelerated the research of TNF. The similarities and differences in the biological functions and the underlying mechanisms that control them among these TNF family members are also important issues to be addressed in the future.

\section{Acknowledgements}

We would like to thank Joseph Lewis and Jennifer Ryan for critical reading of the manuscript. Thus work was supported by grants from the National Institute of Health and the California Cancer Research Program.

\section{References}

Abraham, E., Wunderink, R., Silverman, H., Perl, T.M., Nasraway, S., Levy, H., Bone, R., Wenzel, R.P., Balk, R., and Allred, R. 1995. Efficacy and safety of monoclonal antibody to human tumor necrosis factor alpha in patients with sepsis syndrome. A randomized, controlled, doubleblind, multicenter clinical trial. TNF-alpha MAb Sepsis Study Group. JAMA 273: 934-41.

Adam, D., Wiegmann, K., Adam-Klages, S., Ruff, A., and Kronke, M. 1996. A novel cytoplasmic domain of the p55 tumor necrosis factor receptor initiates the neutral sphingomyelinase pathway. J. Biol. Chem. 271: 1461722.

Adam-Klages, S., Adam, D., Wiegmann, K., Struve, S., Kolanus, W., Schneider-Mergener, J., and Kronke, M. 1996. FAN, a novel WD-repeat protein, couples the p55 TNF-receptor to neutral sphingomyelinase. Cell 86: 937947.

Baeuerle, P.A. and Baltimore, D. 1996. NF-kappaB: Ten years after. Cell 87: 13-20.

Bathon, J.M., Martin, R.W., Fleischmann, R.M., Tesser, J.R., Schiff, M.H., Keystone, E.C., Genovese, M.C., Wasko, M.C., Moreland, L.W., Weaver, A.L., Markenson, J., and Finck, B.K. 2000. A comparison of etanercept and methotrexate in patients with early rheumatoid arthritis. N. Engl. J. Med. 343: 1586-93.

Baud, V., Liu, Z.G., Bennett, B., Suzuki, N., Xia, Y., and Karin, M. 1999. Signaling by proinflammatory cytokines: oligomerization of TRAF2 and TRAF6 is sufficient for JNK and IKK activation and target gene induction via an aminoterminal effector domain. Genes Dev. 13: 1297-308.

Beg, A.A. and Baltimore, D. 1996. An essential role for NF-kappaB in preventing TNF- $\alpha$-induced cell death. Science 274: 782-784.

Beutler, B., Mahoney, J., Trang, N.L., Pekala, P., and Cerami, A. 1984. Purification of cachectin, a lipoprotein lipase-suppressing hormone secreted by endotoxininduced raw 264.7 cells. J. Exp. Med. 161: 984-995.

Beutler, B. and Cerami, A. 1988. Tumor necrosis, cachexia, shock, and inflammation: A common mediator. Ann. Rev. Biochem. 57: 505-518.

Beyaert, R. and Fiers, W. 1994. Molecular mechanisms of tumor necrosis factor-induced cytotoxicity. What we do understand and what we do not. FEBS 340: 9-16.

Boldin, M.P., Goncharov, T.M., Goltsev, Y.V., and Wallach, D. 1996. Involvement of MACH, a novel MORT1/FADDinteracting protease, in Fas/APO-1 and TNF receptorinduced cell death. Cell 85: 803-815. 
Buday, L. 1999. Membrane-targeting of signalling molecules by $\mathrm{SH} 2 / \mathrm{SH} 3$ domain-containing adaptor proteins. Biochim. Biophys. Acta 1422: 187-204.

Carballo, E., Lai, W.S., and Blackshear, P.J. 1998. Feedback inhibition of macrophage tumor necrosis factoralpha production by tristetraprolin. Science 281: 10011005.

Carswell, E.A., Old, L.J., Kassel, R.L., Green, S., Fiore, N., and Williamson, B. 1975. An endotoxin-induced serum factor that causes necrosis of tumors. Proc Natl Acad Sci U S A 72: 3666-3670.

Charles, P.J., Smeenk, R.J., De Jong, J., Feldmann, M., and Maini, R.N. 2000. Assessment of antibodies to double-stranded DNA induced in rheumatoid arthritis patients following treatment with infliximab, a monoclonal antibody to tumor necrosis factor alpha: findings in openlabel and randomized placebo-controlled trials. Arthritis Rheum. 43: 2383-90.

Chen, C.Y., Del Gatto-Konczak, F., Wu, Z., and Karin, M. 1998. Stabilization of interleukin-2 mRNA by the c-Jun NH2-terminal kinase pathway. Science 280: 1945-1949.

Chen, Z.J., Parent, L., and Maniatis, T. 1996. Site-specific phosphorylation of IkappaB by a novel ubiquitinationdependent protein kinase activity. Cell 84: 853-862.

Cohen, J.J., Duke, R.C., Fadok, V.A., and Sellins, K.S. 1992. Apoptosis and programmed cell death in immunity. Annu. Rev. Immunol. 10: 267-93.

Davis, R.J. 1999. Signal transduction by the C-Jun Nterminal kinase. Biochem. Soc. Symp. 64: 1-12.

Deiss, L.P., Galinka, H., Berissi, H., Cohen, O., and Kimchi, A. 1996. Cathepsin D protease mediates programmed cell death induced by interferon-gamma, Fas/APO-1 and TNF-alpha. EMBO J. 15: 3861-3870.

Derijard, B., Hibi, M., Wu, I., Barrett, T., Su, B., Deng, T., Karin, M., and Davis, R.J. 1994. JNK1: A protein kinase stimulated by UV light and $\mathrm{Ha}$-Ras that binds and phosphorylates the c-Jun activation domain. Cell 76: 1025-1037.

Derijard, B., Raingeaud, J., Barrett, T., Wu, I., Han, J., Ulevitch, R.J., and Davis, R.J. 1995. Independent human MAP kinase signal transduction pathways defined by MEK and MKK isoforms. Science 267: 682-685.

Devin, A., Cook, A., Lin, Y., Rodriguez, Y., Kelliher, M., and Liu, Z. 2000. The distinct roles of TRAF2 and RIP in IKK activation by TNF-R1: TRAF2 recruits IKK to TNF-R1 while RIP mediates IKK activation. Immunity. 12: 41929.

Devin, A., Lin, Y., Yamaoka, S., Li, Z., Karin, M., and Liu ZG. 2001. The alpha and beta subunits of lkappaB kinase (IKK) mediate TRAF2-dependent IKK recruitment to tumor necrosis factor (TNF) receptor 1 in response to TNF. Mol. Cell Biol. 21: 3986-94.

DiDonato, J.A., Hayakawa, M., Rothwarf, D.M., Zandi, E., and Karin, M. 1997. A cytokine-responsive IkappaB kinase that activates the transcription factor NF-kappaB. Nature 388: 548-54

Erickson, S.L., de Sauvage, F.J., Kikly, K., Carver-Moore, K., Pitts-Meek, S., Gillett, N., Sheehan, K.C., Schreiber, R.D., Goeddel, D.V., and Moore, M.W. 1994. Decreased sensitivity to tumour-necrosis factor but normal T-cell development in TNF receptor-2-deficient mice. Nature
372: $560-3$

Fan, X.C. and Steitz, J.A. 1998. Overexpression of HuR, a nuclear-cytoplasmic shuttling protein, increases the in vivo stability of ARE-containing mRNAs. EMBO J. 17: 344860.

Faour, W.H., He, Y., He, Q.W., de Ladurantaye, M., Quintero, M., Mancini, A., and Di Battista, J.A. 2001. Prostaglandin E2 regulates the level and stability of cyclooxygenase-2 mRNA through activation of p38 mitogen-activated protein kinase in interleukin-1 $\beta$-treated human synovial fibroblasts. J. Biol. Chem. 276: 3172031

Fiers, W., Beyaert, R., Declercq, W., and Vandenabeele, P. 1999. More than one way to die: apoptosis, necrosis and reactive oxygen damage. Onc. 18: 7719-7730.

Foghsgaard, L., Wissing, D., Mauch, D., Lademann, U., Bastholm, L., Boes, M., Elling, F., Leist, M., and Jaattela, M. 2001. Cathepsin B acts as a dominant execution protease in tumor cell apoptosis induced by tumor necrosis factor. J. Cell Biol. 153: 999-1010.

Golstein, P., Ojcius, D.M., and Young, J.D. 1991. Cell death mechanisms and the immune system. Immunol. Rev. 121: 29-65.

Goossens, V., Grooten, J., De Vos, K., and Fiers, W. 1995. Direct evidence for tumor necrosis factor-induced mitochondrial reactive oxygen intermediates and their involvement in cytotoxicity. Proc. Natl. Acad. Sci. U. S. A. 92: 8115-8119.

Goossens, V., De Vos, K., Vercammen, D., Steemans, M., Vancompernolle, K., Fiers, W., Vandenabeele, P., and Grooten, J. 1999. Redox regulation of TNF signaling. Biofactors 10: 145-156.

Guhaniyogi, J. and Brewer, G. 2001. Regulation of mRNA stability in mammalian cells. Gene 265: 11-23.

Guicciardi, M.E., Deussing, J., Miyoshi, H., Bronk, S.F., Svingen, P.A., Peters, C., Kaufmann, S.H., and Gores, G.J. 2000. Cathepsin B contributes to TNF-alphamediated hepatocyte apoptosis by promoting mitochondrial release of cytochrome c. J. Clin. Invest. 106: 1127-37.

Gupta, S., Barrett, T., Whitmarsh, A.J., Cavanagh, J., Sluss, H.K., Derijard, B., and Davis, R.J. 1996. Selective interaction of JNK protein kinase isoforms with transcription factors. EMBO J. 15: 2760-2770.

Han, J., Brown, T., and Beutler, B. 1990. Endotoxinresponsive sequences control cachectin/tunor necrosis factor biosynthesis at the translational level. J. Exp. Med. 171: 465-475.

Han, J., Lee, J.-D., Bibbs, L., and Ulevitch, R.J. 1994. A MAP kinase targeted by endotoxin and hyperosmolarity in mammalian cells. Science 265: 808-811.

Han, J., Lee, J.-D., Jiang, Y., Li, Z., Feng, L., and Ulevitch, R.J. 1996. Characterization of the structure and function of a novel MAP kinase kinase (MKK6). J. Biol. Chem. 271: 2886-2891.

Heyninck, K., De Valck, D., Vanden Berghe, W., Van Criekinge, W., Contreras, R., Fiers, W., Haegeman, G., and Beyaert, R. 1999. The zinc finger protein A20 inhibits TNF-induced NF-kappaB-dependent gene expression by interfering with an RIP- or TRAF2-mediated transactivation signal and directly binds to a novel NF- 
kappaB-inhibiting protein ABIN. J. Cell Biol. 145: 147182.

Higuchi, M., Singh, S., Jaffrezou, J.P., and Aggarwal, B.B. 1996. Acidic sphingomyelinase-generated ceramide is needed but not sufficient for TNF-induced apoptosis and nuclear factor-kappa B activation. J. Immunol. 157: 297304.

Hildt, E. and Oess, S. 1999. Identification of Grb2 as a novel binding partner of tumor necrosis factor (TNF) receptor I. J. Exp. Med. 189: 1707-14.

Hoeflich, K.P., Luo, J., Rubie, E.A., Tsao, M.S., Jin, O., and Woodgett, J.R. 2000. Requirement for glycogen synthase kinase-3beta in cell survival and NF-kappaB activation. Nature 406: 86-90.

Holler, N., Zaru, R., Micheau, O., Thome, M., Attinger, A., Valitutti, S., Bodmer, J.L., Schneider, P., Seed, B., and Tschopp, J. 2000. Fas triggers an alternative, caspase8-independent cell death pathway using the kinase RIP as effector molecule. Nat. Immunol. 1: 489-95.

Holtmann, H., Enninga, J., Kalble, S., Thiefes, A., Dorrie, A., Broemer, M., Winzen, R., Wilhelm, A., Ninomiya-Tsuji, J., Matsumoto, K., Resch, K., and Kracht, M. 2001. The MAPK kinase kinase TAK1 plays a central role in coupling the interleukin-1 receptor to both transcriptional and RNAtargeted mechanisms of gene regulation. J. Biol. Chem. 276: 3508-16.

Hsu, H., Xiong, J., and Goeddel, D.V. 1995. The TNF receptor 1-asssociated protein TRADD signals cell death and NF-kappaB activation. Cell 81: 495-504.

Hsu, H., Huang, J., Shu, H.B., Baichwal, V., and Goeddel, D.V. 1996a. TNF-dependent recruitment of the protein kinase RIP to the TNF receptor-1 signaling complex. Immunity. 4: 387-96.

Hsu, H., Shu, H.B., Pan, M.G., and Goeddel, D.V. 1996b. TRADD-TRAF2 and TRADD-FADD interactions define two distinct TNF receptor 1 signal transduction pathways. Cell 84: 299-308.

Ichijo, H., Nishida, E., Irie, K., ten Dijke, P., Saitoh, M., Moriguchi, T., Takagi, M., Matsumoto, K., Miyazono, K., and Gotoh, Y. 1997. Induction of apoptosis by ASK1, a mammalian MAPKKK that activates SAPK/JNK and p38 signaling pathways. Science 275: 90-94.

Israel, A., Le Bail, O., Hatat, D., Piette, J., Kieran, M., Logeat, F., Wallach, D., Fellous, M., and Kourilsky, P. 1989. TNF stimulates expression of mouse MHC class I genes by inducing an NF kappa B-like enhancer binding activity which displaces constitutive factors. EMBO J. 8: 3793-800.

Israel, N., Hazan, U., Alcami, J., Munier, A., ArenzanaSeisdedos, F., Bachelerie, F., Israel, A., and Virelizier, J.L. 1989. Tumor necrosis factor stimulates transcription of HIV-1 in human T lymphocytes, independently and synergistically with mitogens. J. Immunol. 143: 3956-60. Janknecht, R. and Hunter, T. 1997. Convergence of MAP kinase pathways on the ternary complex factor Sap-1a.X. EMBO J. 16: 1620-1627.

Kallunki, T., Deng, T., Hibi, M., and Karin, M. 1996. c-Jun can recruit JNK to phosphorylate dimerization partners via specific docking interactions. Cell 87: 929-39.

Kane, D.J., Sarafian, T.A., Anton, R., Hahn, H., Gralla, E.B., Valentine, J.S., Ord, T., and Bredesen, D.E. 1993. Bcl-2 inhibition of neural death: decreased generation of reactive oxygen species. Science 262: 1274-1277.

Karin, M. and Ben-Neriah, Y. 2000. Phosphorylation meets ubiquitination: the control of NF-[kappa]B activity. Annu. Rev. Immunol. 18: 621-63.

Kelliher, M.A., Grimm, S., Ishida, Y., Kuo, F., Stanger, B.Z., and Leder, P. 1998. The death domain kinase RIP mediates the TNF-induced NF-kappaB signal. Immunity. 8: 297-303.

Kerr, J.F., Wyllie, A.H., and Currie, A.R. 1972. Apoptosis: a basic biological phenomenon with wide-ranging implications in tissue kinetics. Br J Cancer 26: 239-257. Kontoyiannis, D., Pasparakis, M., Pizarro, T.T., Cominelli, F., and Kollias, G. 1999. Impaired on/off regulation of TNF biosynthesis in mice lacking TNF AU-rich elements: implications for joint and gut-associated immunopathologies. Immunity. 10: 387-398.

Kontoyiannis, D., Kotlyarov, A., Carballo, E., Alexopoulou, L., Blackshear, P.J., Gaestel, M., Davis, R., Flavell, R., and Kollias, G. 2001. Interleukin-10 targets p38 MAPK to modulate ARE-dependent TNF mRNA translation and limit intestinal pathology. EMBO J. 20: 3760-3770.

Kotlyarov A., Neininger A., Schubert C., and Gaestel M. 1999. MAPKAP kinase 2 is essential for LPS-induced TNF-a biosynthesis. Nature Cell Biology 1: 94-97.

Kreder, D., Krut, O., Adam-Klages, S., Wiegmann, K., Scherer, G., Plitz, T., Jensen, J.M., Proksch, E., Steinmann, J., Pfeffer, K., and Kronke, M. 1999. Impaired neutral sphingomyelinase activation and cutaneous barrier repair in FAN-deficient mice. EMBO J. 18: 24722479.

Kremer, J.M. 2001. Rational use of new and existing disease-modifying agents in rheumatoid arthritis. Ann. Intern. Med. 134: 695-706.

Kull, F.C. and Cuatrecasas, P. 1981. Possible requirement of internalization in the mechanism of in vitro cytotoxicity in tumor necrosis serum. Cancer Res. 41: 4885-90.

Lasa, M., Mahtani, K.R., Finch, A., Brewer, G., Saklatvala, J., and Clark, A.R. 2000. Regulation of cyclooxygenase 2 mRNA stability by the mitogen-activated protein kinase p38 signaling cascade. Mol. Cell Biol. 20: 4265-74.

Lasa, M., Brook, M., Saklatvala, J., and Clark, A.R. 2001. Dexamethasone destabilizes cyclooxygenase 2 mRNA by inhibiting mitogen-activated protein kinase p38. Mol. Cell Biol. 21: 771-80.

Lee, E.G., Boone, D.L., Chai, S., Libby, S.L., Chien, M., Lodolce, J.P., and Ma, A. 2000. Failure to regulate TNFinduced NF-kappaB and cell death responses in A20deficient mice. Science 289: 2350-4.

Lee, F.S., Hagler, J., Chen, Z.J., and Maniatis, T. 1997. Activation of the IkappaBa kinase complex by MEKK1, a kinase of the JNK pathway. Cell 88: 213-222.

Levkowitz, G., Waterman, H., Ettenberg, S.A., Katz, M., Tsygankov, A.Y., Alroy, I., Lavi, S., Iwai, K., Reiss, Y., Ciechanover, A., Lipkowitz, S., and Yarden, Y. 1999. Ubiquitin ligase activity and tyrosine phosphorylation underlie suppression of growth factor signaling by c-Cbl/ Sli-1. Mol. Cell 4: 1029-40.

$\mathrm{Li}, \mathrm{H}$. and Yuan, J. 1999. Deciphering the pathways of life and death. Curr. Opin. Cell Biol. 11: 261-266.

Liddil, J.D., Dorr, R.T., and Scuderi, P. 1989. Association 
of lysosomal activity with sensitivity and resistance to tumor necrosis factor in murine L929 cells. Cancer Res. 49: 2722-2728.

Lin, Y., Devin, A., Rodriguez, Y., and Liu, Z.G. 1999. Cleavage of the death domain kinase RIP by caspase-8 prompts TNF-induced apoptosis. Genes Dev. 13: 251426.

Liu, Z.G., Hsu, H., Goeddel, D.V., and Karin, M. 1996. Dissection of TNF receptor 1 effector functions: JNK activation is not linked to apoptosis while NF-kappaB activation prevents cell death. Cell 87: 565-76.

Lozano, J., Menendez, S., Morales, A., Ehleiter, D., Liao, W.C., Wagman, R., Haimovitz-Friedman, A., Fuks, Z., and Kolesnick, R. 2001. Cell autonomous apoptosis defects in acid sphingomyelinase knockout fibroblasts. J. Biol. Chem. 276: 442-8.

Malinin, N.L., Boldin, M.P., Kovalenko, A.V., and Wallach, D. 1997. MAP3K-realted kinase involved in NF-kappaB induction by TNF, CD95 and IL-1. Nature 385: 540-544.

Mercurio, F., Zhu, H., Murray, B.W., Shevchenko, A., Bennett, B.L., Li, J.W., Young, D.B., Barbosa, M., and Mann, M. 1997. IKK-1 and IKK-2: Cytokine-activated IkappaB kinases essential for NF-kappaB activation. Science 278: 860-866.

Mikuls, T.R. and Moreland, L.W. 2001. TNF blockade in the treatment of rheumatoid arthritis: infliximab versus etanercept. Expert. Opin. Pharmacother. 2: 75-84.

Mohit, A.A., Martin, J.H., and Miller, C.A. 1995. p493F12 kinase: a novel MAP kinase expressed in a subset of neurons in the human nervous system. Neuron 14: 6778.

Monney, L., Olivier, R., Otter, I., Jansen, B., Poirier, G.G., and Borner, C. 1998. Role of an acidic compartment in tumor-necrosis-factor-alpha-induced production of ceramide, activation of caspase-3 and apoptosis. Eur. J. Biochem. 251: 295-303.

Nagata, S. and Golstein, P. 1995. The Fas death factor. Science 267: 1449-1456.

Nanda, A., Gukovskaya, A., Tseng, J., and Grinstein, S. 1992. Activation of vacuolar-type proton pumps by protein kinase $\mathrm{C}$. Role in neutrophil $\mathrm{pH}$ regulation. J. Biol. Chem. 267: 22740-22746.

Natoli, G., Costanzo, A., Ianni, A., Templeton, D.J., Woodgett, J.R., Balsano, C., and Levrero, M. 1997. Activation of SAPK/JNK by TNF receptor 1 through a noncytotoxic TRAF2-dependent pathway. Science 275: 200-3.

Nguyen, L.T., Duncan, G.S., Mirtsos, C., Ng, M., Speiser, D.E., Shahinian, A., Marino, M.W., Mak, T.W., Ohashi, P.S., and Yeh, W.C. 1999. TRAF2 deficiency results in hyperactivity of certain TNFR1 signals and impairment of CD40-mediated responses. Immunity. 11: 379-89.

Ono, K. and Han, J. 2000. The p38 signal transduction pathway: activation and function. Cell Signal. 12: 1-13.

Opipari, A.W., Boguski, M.S., and Dixit, V.M. 1990. The A20 cDNA induced by tumor necrosis factor alpha encodes a novel type of zinc finger protein. J. Biol. Chem. 265: $14705-8$.

Peng, S.S., Chen, C.Y., Xu, N., and Shyu, A.B. 1998. RNA stabilization by the AU-rich element binding protein, HuR, an ELAV protein. EMBO J. 17: 3461-70.
Pfeffer, K., Matsuyama, T., Kundig, T.M., Wakeham, A., Kishihara, K., Shahinian, A., Wiegmann, K., Ohashi, P.S., Kronke, M., and Mak, T.W. 1993. Mice deficient for the $55 \mathrm{kd}$ tumor necrosis factor receptor are resistant to endotoxic shock, yet succumb to L. monocytogenes infection. Cell 73: 457-467.

Piecyk, M., Wax, S., Beck, A.R., Kedersha, N., Gupta, M., Maritim, B., Chen, S., Gueydan, C., Kruys, V., Streuli, M., and Anderson, P. 2000. TIA-1 is a translational silencer that selectively regulates the expression of TNF-alpha. EMBO J. 19: 4154-63.

Raingeaud, J., Gupta, S., Rogers, J.S., Dickens, M., Han, J., Ulevitch, R.J., and David, R.J. 1995. Pro-inflammatory cytokines and environmental stress cause p38 MAP kinase activation by dual phosphorylation on tyrosine and threonine. J. Biol. Chem. 270: 7420-7426.

Regnier, C.H., Song, H.Y., Gao, X., Goeddel, D.V., Cao, Z., and Rothe, M. 1997. Identification and characterization of an IkappaB kinase. Cell 90: 373-383.

Robinson, M.J. and Cobb, M.H. 1997. Mitogen-activated protein kinase pathways. Curr. Opin. Cell Biol. 9: 180186.

Rothe, J., Gehr, G., Loetscher, H., and Lesslauer, W. 1992. Tumor necrosis factor receptors-structure and function. Immunol. Res. 11: 81-90.

Rothe, M., Wong, S.C., Henzel, W.J., and Goeddel, D.V. 1994. A novel family of putative signal transducers associated with the cytoplasmic domain of the $75 \mathrm{kDa}$ tumor necrosis factor receptor. Cell 78: 681-692.

Rothe, M., Sarma, V., Dixit, V.M., and Goeddel, D.V. 1995. TRAF2-mediated activation of NF-kappaB by TNF receptor 2 and CD40. Science 269: 1424-1427.

Rothwarf, D.M., Zandi, E., Natoli, G., and Karin, M. 1998. IKK-gamma is an essential regulatory subunit of the IkappaB kinase complex. Nature 395: 297-300.

Sanz, L., Sanchez, P., Lallena, M.J., Diaz-Meco, M.T., and Moscat, J. 1999. The interaction of p62 with RIP links the atypical PKCs to NF-kappaB activation. EMBO J. 18: 3044-53.

Schaible, T.F. 2000. Long term safety of infliximab. Can. J. Gastroenterol. 14 Suppl C: 29C-32C.

Schutze, S., Potthoff, K., Machleidt, T., Berkovic, D., Wiegmann, K., and Kronke, M. 1992. TNF activates NFkB by phosphatidylcholine-specific phospholipase Cinduced "acidic" sphingomyelin breakdown. Cell 71: 765776.

Segui, B., Bezombes, C., Uro-Coste, E., Medin, J.A., Andrieu-Abadie, N., Auge, N., Brouchet, A., Laurent, G., Salvayre, R., Jaffrezou, J.P., and Levade, T. 2000. Stressinduced apoptosis is not mediated by endolysosomal ceramide. FASEB J. 14: 36-47.

Segui, B., Cuvillier, O., Adam-Klages, S., Garcia, V., Malagarie-Cazenave, S., Leveque, S., Caspar-Bauguil, S., Coudert, J., Salvayre, R., Kronke, M., and Levade, T. 2001. Involvement of FAN in TNF-induced apoptosis. J. Clin. Invest. 108: 143-51.

Shaw, G. and Kamen, R. 1986. A conserved AU sequence from the 3 ' untranslated region of GM-CSF mRNA mediates selective mRNA degradation. Cell 46: 659-667. Sheng, H., Shao, J., and DuBois, R.N. 2001. K-Rasmediated increase in cyclooxygenase 2 mRNA stability 
involves activation of the protein kinase B1. Cancer Res. 61: 2670-5.

Shimizu, S., Eguchi, Y., Kosaka, H., Kamiike, W., Matsuda, H., and Tsujimoto, Y. 1995. Prevention of hypoxia-induced cell death by Bcl-2 and Bcl-xL. Nature 374: 811-813.

Shu, H.B., Takeuchi, M., and Goeddel, D.V. 1996. The tumor necrosis factor receptor 2 signal transducers TRAF2 and c-IAP1 are components of the tumor necrosis factor receptor 1 signaling complex. Proc. Natl. Acad. Sci. U. S. A. 93: 13973-8.

Shyu, A.B. and Wilkinson, M.F. 2000. The double lives of shuttling mRNA binding proteins. Cell 102: 135-8.

Sluss, H.K., Barrett, T., Derijard, B., and Davis, R.J. 1994. Signal transduction by tumor necrosis factor mediated by JNK protein kinases. Mol. Cell Biol. 14: 8376-84.

Smith, C.A., Farrah, T., and Goodwin, R.G. 1994. The TNF receptor superfamily of cellular and viral proteins: Activation, costimulation, and death. Cell 76: 959-962.

Srinivasan, A., Li, F., Wong, A., Kodandapani, L., Smidt, R.J., Krebs, J.F., Fritz, L.C., Wu, J.C., and Tomaselli, K.J. 1998. Bcl-xL functions downstream of caspase-8 to inhibit Fas- and tumor necrosis factor receptor 1-induced apoptosis of MCF7 breast carcinoma cells. J. Biol. Chem. 273: 4523-9.

Stoka, V., Turk, B., Schendel, S.L., Kim, T.H., Cirman, T., Snipas, S.J., Ellerby, L.M., Bredesen, D., Freeze, H., Abrahamson, M., Bromme, D., Krajewski, S., Reed, J.C., Yin, X.M., Turk, V., and Salvesen, G.S. 2001. Lysosomal protease pathways to apoptosis: cleavage of bid, not Procaspases, is the most likely route. J. Biol. Chem. 276: 3149-3157.

Stout, L.C., Kumar, S., and Whorton, E.B. 1993. Focal mesangiolysis and the pathogenesis of the KimmelstielWilson nodule. Hum. Pathol. 24: 77-89.

Strasser, A., O'Connor, L., and Dixit, V.M. 2000. Apoptosis signaling. Annu. Rev. Biochem. 69: 217-45.

Sugarman, B.J., Aggarwal, B.B., Hass, P.E., Figari, I.S., Palladino, M.A., and Shepard, H.M. 1985. Recombinant human tumor necrosis factor-alpha: effects on proliferation of normal and transformed cells in vitro. Science 230: 943-5.

Swantek, J.L., Cobb, M.H., and Geppert, T.D. 1997. Jun $\mathrm{N}$-terminal kinase/stress-activated protein kinase (JNK/ SAPK) is required for lipopolysaccharide stimulation of tumor necrosis factor alpha (TNF-alpha) translation: glucocorticoids inhibit TNF-alpha translation by blocking JNK/SAPK. Mol. Cell Biol. 17: 6274-6282.

Tartaglia, L.A. and Goeddel, D.V. 1992. Two TNF receptors. Immunol. Today 13: 151-3.

Tewari, M. and Dixit, V.M. 1995. Fas- and tumor necrosis factor-induced apoptosis in inhibited by the poxvirus crmA gene product. J. Biol. Chem. 270: 3255-3260.

Tobiume, K., Matsuzawa, A., Takahashi, T., Nishitoh, H., Morita, K., Takeda, K., Minowa, O., Miyazono, K., Noda, T., and Ichijo, H. 2001. ASK1 is required for sustained activations of JNK/p38 MAP kinases and apoptosis. EMBO Rep. 2: 222-8.

Tournier, C., Dong, C., Turner, T.K., Jones, S.N., Flavell, R.A., and Davis, R.J. 2001. MKK7 is an essential component of the JNK signal transduction pathway activated by proinflammatory cytokines. Genes Dev. 15:
1419-26.

Tracey, K.J. and Cerami, A. 1993. Tumor necrosis factor, other cytokines and disease. Annu. Rev. Cell Biol. 9: 31743.

Van Antwerp, D.J., Martin, S.J., Kafri, T., Green, D.R., and Verma, I.M. 1996. Suppression of TNF- $\alpha$-induced apoptosis by NF-kappaB. Science 274: 787-789.

Van Antwerp, D.J., Martin, S.J., Verma, I.M., and Green, D.R. 1998. Inhibition of TNF-induced apoptosis by NFkappa B. Trends. Cell Biol. 8: 107-11.

van Dullemen, H.M., van Deventer, S.J., Hommes, D.W., Bijl, H.A., Jansen, J., Tytgat, G.N., and Woody, J. 1995. Treatment of Crohn's disease with anti-tumor necrosis factor chimeric monoclonal antibody (cA2). Gastroenterology 109: 129-35.

Vandevoorde, V., Haegeman, G., and Fiers, W. 1997. Induced expression of trimerized intracellular domains of the human tumor necrosis factor (TNF) p55 receptor elicits TNF effects. J. Cell Biol. 137: 1627-1638.

Vercammen, D., Beyaert, R., Denecker, G., Goossens, V., Van Loo, G., Declercq, W., Grooten, J., Fiers, W., and Vandenabeele, P. 1998. Inhibition of caspases increases the sensitivity of L929 cells to necrosis mediated by tumor necrosis factor. J. Exp. Med. 187: 1477-1485.

Wang, C.Y., Mayo, M.W., and Baldwin, A.S. 1996. TNFand cancer therapy-induced apoptosis: potentiation by inhibition of NF-kappaB. Science 274: 784-7.

Wang, X., Ono, K., Kim, S.O., Kravchenko, V., Lin, S.C., and Han, J. 2001. Metaxin is required for tumor necrosis factor-induced cell death. EMBO Rep. 2: 628-633.

Wherry, J.C., Pennington, J.E., and Wenzel, R.P. 1993. Tumor necrosis factor and the therapeutic potential of anti-tumor necrosis factor antibodies. Crit. Care Med. 21: S436-40.

Whitmarsh, A.J. and Davis, R.J. 1996. Transcription factor $A P-1$ regulation by mitogen-activated protein kinase signal transduction pathways. J. Mol. Med. 74: 589-607.

Wiegmann, K., Schutze, S., Machleidt, T., Witte, D., and Kronke, M. 1994. Functional dichotomy of neutral and acidic sphingomyelinases in tumor necrosis factor signaling. Cell 78: 1005-15.

Wiegmann, K., Schwandner, R., Krut, O., Yeh, W.C., Mak, T.W., and Kronke, M. 1999. Requirement of FADD for tumor necrosis factor-induced activation of acid sphingomyelinase. J. Biol. Chem. 274: 5267-70.

Woronicz, J.D., Gao, X., Cao, Z., Rothe, M., and Goeddel, D.V. 1997. IkappaB kinase-beta: NF-kappaB activation and complex formation with IkappaB kinase-alpha and NIK. Science 278: 866-9.

Wright, S.C., Kumar, P., Tam, A.W., Shen, N., Varma, M., and Larrick, J.W. 1992. Apoptosis and DNA fragmentation precede TNF-induced cytolysis in U937 cells. J. Cell Biochem. 48: 344-55.

Wu, M.X., Ao, Z., Prasad, K.V., Wu, R., and Schlossman, S.F. 1998. IEX-1L, an apoptosis inhibitor involved in NFkappaB-mediated cell survival. Science 281: 998-1001.

Xia, Y., Makris, C., Su, B., Li, E., Yang, J., Nemerow, G.R., and Karin, M. 2000. MEK kinase 1 is critically required for C-Jun $\mathrm{N}$-terminal kinase activation by proinflammatory stimuli and growth factor-induced cell migration. Proc. Natl. Acad. Sci. U. S. A. 97: 5243-8. 
Yamaoka, S., Courtois, G., Bessia, C., Whiteside, S.T., Weil, R., Agou, F., Kirk, H.E., Kay, R.J., and Israel, A. 1998. Complementation cloning of NEMO, a component of the IkappaB kinase complex essential for NF-kappaB activation. Cell 93: 1231-40.

Yang, J., Lin, Y., Guo, Z., Cheng, J., Huang, J., Deng, L., Liao, W., Chen, Z., Liu Z-G, and Su, B. 2001. The essential role of MEKK3 in TNF-induced NF-kappaB activation. Nat. Immunol. 2: 620-4.

Yang, Y.L. and Li, X.M. 2000. The IAP family: endogenous caspase inhibitors with multiple biological activities. Cell Res. 10: 169-77.

Yao, B., Zhang, Y., Delikat, S., Mathias, S., Basu, S., and Kolesnick, R. 1995. Phosphorylation of Raf by ceramideactivated protein kinase. Nature 378: 307-310.

Yeh, W.C., Shahinian, A., Speiser, D., Kraunus, J., Billia, F., Wakeham, A., de la Pompa, J.L., Ferrick, D., Hum, B., Iscove, N., Ohashi, P., Rothe, M., Goeddel, D.V., and Mak, T.W. 1997. Early lethality, functional NF-kappaB activation, and increased sensitivity to TNF-induced cell death in TRAF2-deficient mice. Immunity. 7: 715-25.

Yin, L., Wu, L., Wesche, H., Arthur, C.D., White, J.M., Goeddel, D.V., and Schreiber, R.D. 2001. Defective lymphotoxin-beta receptor-induced NF-kappaB transcriptional activity in NIK-deficient mice. Science 291: 2162-5.

Yujiri, T., Ware, M., Widmann, C., Oyer, R., Russell, D., Chan, E., Zaitsu, Y., Clarke, P., Tyler, K., Oka, Y., Fanger, G.R., Henson, P., and Johnson, G.L. 2000. MEK kinase 1 gene disruption alters cell migration and c-Jun $\mathrm{NH}$ terminal kinase regulation but does not cause a measurable defect in NF-kappa B activation. Proc. Natl. Acad. Sci. U. S. A. 97: 7272-7.

Zandi, E., Rothwarf, D.M., Delhase, M., Hayakawa, M., and Karin, M. 1997. The IkappaB kinase complex (IKK) contains two kinase subunits, IKK $\alpha$ and IKK $\beta$, necessary for IkappaB phosphorylation and NFkappaB activation. Cell 91: 243-252.

Zazgornik, J., Schmidt, P., Kopsa, H., and Deutsch, E. 1975. Liver function after renal transplantation. Med. Chir. Dig. 4: 81-4.

Zhang, S.Q., Kovalenko, A., Cantarella, G., and Wallach, D. 2000. Recruitment of the IKK signalosome to the p55 TNF receptor: RIP and A20 bind to NEMO (IKKgamma) upon receptor stimulation. Immunity. 12: 301-11.

Zhang, Y., Yao, B., Delikat, S., Bayoumy, S., Lin, X.-H., Basu, B., McGinley, M., Chan-Hui, P.-Y., Lichenstein, H., and Kolesnick, R. 1997. Kinase suppressor of Ras is ceramide-activated protein kinase. Cell 89: 63-72.

Zumbansen, M. and Stoffel, W. 1997. Tumor necrosis factor $\alpha$ activates NF-kB in acid sphingomyelinase-deficient mouse embryonic fibroblasts. J. Biol. Chem. 272: 1090410909. 


\section{Further Reading}

Caister Academic Press is a leading academic publisher of advanced texts in microbiology, molecular biology and medical research. Full details of all our publications at caister.com

- MALDI-TOF Mass Spectrometry in Microbiology Edited by: M Kostrzewa, S Schubert (2016) www.caister.com/malditof

- Aspergillus and Penicillium in the Post-genomic Era Edited by: RP Vries, IB Gelber, MR Andersen (2016) www.caister.com/aspergillus2

- The Bacteriocins: Current Knowledge and Future Prospects Edited by: RL Dorit, SM Roy, MA Riley (2016)

www.caister.com/bacteriocins

- Omics in Plant Disease Resistance Edited by: V Bhadauria (2016) www.caister.com/opd

- Acidophiles: Life in Extremely Acidic Environments Edited by: R Quatrini, DB Johnson (2016) www.caister.com/acidophiles

- Climate Change and Microbial Ecology: Current Research and Future Trend

Edited by: J Marxsen (2016)

www.caister.com/climate

- Biofilms in Bioremediation: Current Research and Emerging Technologies

Edited by: G Lear (2016)

www.caister.com/biorem

- Microalgae: Current Research and Applications Edited by: MN Tsaloglou (2016) www.caister.com/microalgae

- Gas Plasma Sterilization in Microbiology: Theory, Applications, Pitfalls and New Perspectives Edited by: H Shintani, A Sakudo (2016) www.caister.com/gasplasma

- Virus Evolution: Current Research and Future Directions Edited by: SC Weaver, M Denison, M Roossinck, et al. (2016) www.caister.com/virusevol

- Arboviruses: Molecular Biology, Evolution and Control Edited by: N Vasilakis, DJ Gubler (2016) www.caister.com/arbo

- Shigella: Molecular and Cellular Biology Edited by: WD Picking, WL Picking (2016) www.caister.com/shigella

-Aquatic Biofilms: Ecology, Water Quality and Wastewater Treatment

Edited by: AM Romaní, H Guasch, MD Balaguer (2016)

www.caister.com/aquaticbiofilms

- Alphaviruses: Current Biology

Edited by: S Mahalingam, L Herrero, B Herring (2016)

www.caister.com/alpha

- Thermophilic Microorganisms

Edited by: F Li (2015)

www.caister.com/thermophile
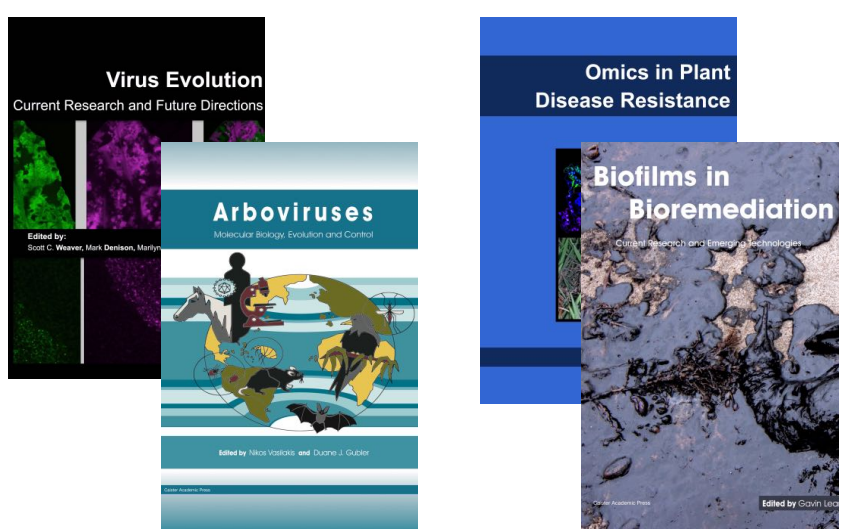
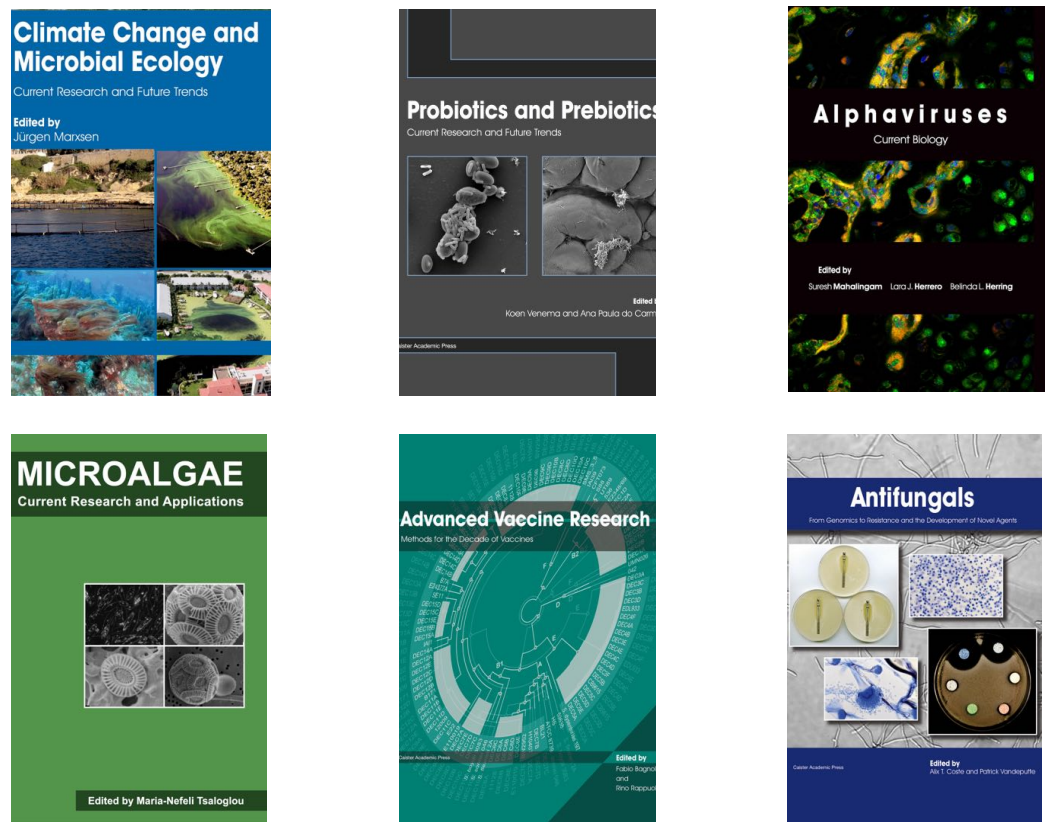

- Flow Cytometry in Microbiology: Technology and Applications Edited by: MG Wilkinson (2015) www.caister.com/flow

- Probiotics and Prebiotics: Current Research and Future Trends Edited by: K Venema, AP Carmo (2015) www.caister.com/probiotics

- Epigenetics: Current Research and Emerging Trends Edited by: BP Chadwick (2015) www.caister.com/epigenetics2015

- Corynebacterium glutamicum: From Systems Biology to Biotechnological Applications

Edited by: A Burkovski (2015)

www.caister.com/cory2

- Advanced Vaccine Research Methods for the Decade of Vaccines

Edited by: F Bagnoli, R Rappuoli (2015)

www.caister.com/vaccines

- Antifungals: From Genomics to Resistance and the Development of Novel Agents

Edited by: AT Coste, P Vandeputte (2015)

www.caister.com/antifungals

- Bacteria-Plant Interactions: Advanced Research and Future Trends Edited by: J Murillo, BA Vinatzer, RW Jackson, et al. (2015) www.caister.com/bacteria-plant

\section{- Aeromonas}

Edited by: J Graf (2015)

www.caister.com/aeromonas

- Antibiotics: Current Innovations and Future Trends

Edited by: S Sánchez, AL Demain (2015)

www.caister.com/antibiotics

- Leishmania: Current Biology and Contro Edited by: S Adak, R Datta (2015) www.caister.com/leish2

- Acanthamoeba: Biology and Pathogenesis (2nd edition) Author: NA Khan (2015)

www.caister.com/acanthamoeba2

- Microarrays: Current Technology, Innovations and Applications Edited by: Z He (2014)

www.caister.com/microarrays2

- Metagenomics of the Microbial Nitrogen Cycle: Theory, Methods and Applications

Edited by: D Marco (2014)

www.caister.com/n2 